\title{
Morpho-structural Study of the Pancreas and Pancreatic Duct in Ostrich (Struthio camelus L.)
}

\author{
M. R. STORNELLI, M. P. RICCIARDI, V. MIRAGLIOTTA, A. COLI, E. GIANNESSI \\ Department of Veterinary Anatomy, Biochemistry and Physiology, Pisa, Italy
}

Received July 25, 2005

Accepted March 16, 2006

\begin{abstract}
Stornelli M. R., M. P. Ricciardi, V. Miragliotta, A. Coli, E. Giannessi: Morphostructural Study of the Pancreas and Pancreatic Duct in Ostrich (Struthio camelus L.). Acta Vet. Brno 2006, 75: 157-160.

The peculiarity of the digestive process in ostrich and the lack of bibliographic data on the pancreas and its excretory system in this species led us to undertake macroscopical and histological investigations to explore possible differences compared to other avian species. Our findings demonstrated the presence of two pancreatic lobes, dorsal and ventral, and a third lobe, the splenic lobe, detectable only histologically. The most interesting data concerned the number, course, drainage and structural peculiarities of the pancreatic duct. The structural and ultrastructural features of the two cell types lining the pancreatic duct (main cells and globose cells) were suggestive of their role in secretion and resorption of the pancreatic juice. The results allow the understanding of the particular digestive process of this species.
\end{abstract}

Ostrich, pancreas, pancreatic duct, structure, ultrastructure

The pancreas of birds is located in the duodenal loop and is divided into lobes whose number and denomination vary according to species. The literature on the avian pancreas reports that it is composed of a ventral lobe, which in some cases is divided into two portions called principal and accessory lobe, a dorsal and a splenic lobe. The latter is not always clearly visible and represents a prolongation of the dorsal lobe. Furthermore, bibliographical data report significant differences among avian species with regard to the number, course and drainage of the main excretory ducts (Botte and Pelagalli 1982; Liu et al. 1998; Nickel et al. 1984; Paik et al. 1974; Sisson and Grossman 1982; Turk 1983; Vinnicombe and Kendall 1983). The variability of this pattern led us to investigate the morphology and the structure of the pancreas and its excretory system (in particular the pancreatic duct) in ostrich, a species on which only scanty information is available (Bezuidenhout 1986). The ostrich is of particular interest not only for food production, but also on account of the peculiar features of its digestive process, which involves constant food intake throughout the day and requires continuous production of pancreatic juice.

\section{Materials and Methods}

For this study we used a total of 10 ostriches of both sexes, with the age range between 16 and 18 months, reared on the same ostrich farm and slaughtered in conformity with the regulations in force in Italy. First, the pancreas and its excretory ducts were observed in situ in order to describe their position, morphology and relationship. Portions of the gland from the cranial, median and caudal part of the dorsal and ventral lobes, and portions of the pancreatic duct from its free and intraduodenal part from each subject were sampled. Some of the samples were fixed in salted formalin and Bouin's solution for paraffin embedding and $8 \mathrm{~mm}$ serial sections were stained with H/E, PAS/H and toluidine blue. Samples of the pancreatic duct were fixed in $2.5 \%$ glutaraldehyde and post-fixed in $1 \%$ osmium tetroxide for embedding in epoxy resin; the semithin sections were stained with a $1 \%$ mixture of toluidine blue and methylene blue. The height of the epithelial cells of the pancreatic duct and the maximum diameter of their nuclei were measured using a Leica Q Win image analyzer. The ultrathin sections, after double staining with uranyl acetate and lead citrate, were observed by TEM.

Address for correspondence:

Dr. Maria Rita Stornelli

Dipartimento di Anatomia, Biochimica e Fysiologia Veterinaria

Università di Pisa, Viale delle Piagge 2

56124 Pisa, Italia
Phone: +390502216863

Fax: +390502216868

E-mail: rsotrnel@vet.unipi.it

http://www.vfu.cz/acta-vet/actavet.htm 


\section{Results}

Macroscopic anatomy

The ostrich pancreas almost completely occupies the duodenal loop, extending from the pylorus to the loop between the two duodenal limbs, which together almost totally cover the pancreas itself. The pancreas consists of two lobes: the dorsal one, more developed lengthwise, which is oriented towards the descending duodenal limb, and the ventral one, shorter, lying adjacent to the ascending duodenal limb. The lobes, connected by parenchymal bridges, are further subdivided into fairly voluminous lobules. The majority of subjects show a single pancreatic duct, originating from the confluence of two large intralobar ducts which extend axially through the lobes. The duct emerges from the pancreatic hilum in front of the secondary duodenal loop characteristic of the ascending duodenum in ostrich (Plate I, Fig. 1). Shortly afterwards it enters the duodenal wall obliquely until it opens into a papilla placed at a distance of $2-3 \mathrm{~cm}$ from the secondary duodenal loop (Plate I, Fig. 2a). Exceptionally, two pancreatic ducts following a parallel course and opening together into the papilla were observed (Plate I, Fig. 2b).

\section{Light microscopy}

Light microscopy of the pancreas shows a splenic lobe that is not macroscopically visible and is located in the more cranial portion of the dorsal lobe. All lobes are composed of large parenchymal lobules supported by a thin reticular stroma. In the acinar exocrine component, type $\alpha$ (dark) and type $\beta$ (clear) islets of Langerhans, particularly noticeable in the splenic lobe, can be detected.

The excretory system consists of small calibre ducts lined with simple cubicoidal epithelium emptying the secretion into the two large intralobar ducts that extend axially in the dorsal and ventral lobe. The pancreatic duct originates from the confluence of the two intralobar ducts and it is organized in a tunica mucosa, raised into more or less complicated folds and lined with simple columnar epithelium constituted from two types of epithelial cells called main cells and globose cells.

The main cells, the most numerous, are very tall $(27.42 \pm 3.89 \mu \mathrm{m})$, with microvilli and with cell limits not always clearly identifiable. They present an ovoidal euchromatic nucleus (greatest diameter $7.90 \pm 1.35 \mu \mathrm{m}$ ) with a regular outline, containing 1 or 2 nucleoli, located in the middle or in the basal portion of the cell. The cytoplasm contains PAS-positive and metachromatic granules, detectable in the upper third of the cell (Plate II, Fig. 4ab). These granules are responsible for a fairly thick film of mucopolysaccharidic material forming the glycocalyx of the epithelium. Observation of semithin sections led to the detection of their variable tinctorial affinity and to point out the other cellular type named globose cells. These latter cells, scantily represented, are extremely large (greatest diameter $15.95 \pm 4.55 \mu \mathrm{m}$; smallest diameter $10.16 \pm 1.41 \mu \mathrm{m}$ ), and they are located at different height within the thickness of the epithelium. Their cytoplasm exhibits weak tinctorial affinity, is devoid of granules and contains a large rounded and euchromatic nucleus (Plate II, Fig. 4c). The lamina propria frequently contains nodules of pancreatic exocrine tissue with small excretory ducts, whereas the endocrine component is absent; such nodules may be particularly large, thus reducing the height of the overlying epithelium (Plate II, Fig. 3). Throughout the length of the duct, no mucous glands can be detected.

The tunica submucosa is thin and the tunica muscularis is arranged in a thick longitudinal and circular pattern with bundles extending in a regular manner compacted by collagenous fibers; in the intraduodenal tract the muscle component is progressively reduced until it results formed by small discontinuous muscle fasciculi.

\section{Electron microscopy}

Electron microscopy gave full details of the of main and globose cells. The main cells are endowed with sparse microvilli of different length and present spherical-shaped electron- 
dense granules (sometimes provided with an electron-lucent core) variable in size and quantity, localized almost exclusively between the nucleus and the apical portion of the cell. Among the granules there are numerous oval mitochondria, with tubular cristae and a matrix very slightly electron-dense (Plate III, Fig. 5). The Golgi apparatus is composed of 5-6 cisternae; clear vacuoles with a membrane near the nucleus can be observed. The rough endoplasmic reticulum (RER) and ribosomes, either free or organized into long chains, are abundant (Plate III, Fig. 6). Between adjacent cells adhesion complex are clearly visible. The globose cells, devoid of granules and microvilli, are neither PAS-positive nor metachromatic. They contain numerous swollen mitochondria and clear vesicles provided with membrane. The RER, free ribosomes and Golgi apparatus are scantily represented (Plate IV, Fig. 7). Globose and main cells are linked by evident adhesion structures.

\section{Discussion}

Our results showed that the ostrich pancreas does not differ substantially from findings reported for other avian species since it presents three lobes: the dorsal lobe, the ventral lobe, sometimes divided into two portions, and the splenic lobe, which in the ostrich is detectable only histologically. Microscopically, the endocrine component, consististing of type $\alpha$ and type $\beta$ islets of Langerhans, is particularly concentrated in the splenic lobe.

Considerable differences related to the number, course and opening of the pancreatic duct were found instead. In fact, our findings indicate that in ostrich, there is generally a single pancreatic duct, opening into the ascending duodenum independently of the hepatoenteric duct, while three main ducts in the gallinaceans (Botte and Pelagalli 1982; Nickel et al. 1984; Paik et al. 1974; Sisson and Grossman 1982), from two to four ducts in the duck (Liu et al. 1998), and numerous ducts in the starling (Vinnicombe and Kendall 1983) are described.

Our structural study of the ostrich pancreatic duct highlights the presence of accessory pancreatic tissue in the lamina propria as reported by Liu (1998) for the duck. Moreover, the observed lack of mucous glands in the pancreatic duct of the ostrich can be compensated by the presence of the main cells. In fact these latter cells with their PAS-positive and metachromatic content, visible as electron-dense granules on TEM, and the abundant RER and Golgi apparatus, are able to produce a constant quantity of mucopolysaccharides constituting a glycocalyx that protects the mucosa from the action of pancreatic juice. Because they are endowed with microvilli and abundant mitochondria, the main cells could also be able to perform the process of resorption.

Regarding the globose cells, we disagree with Weyrauch and Schnorr (1978), who defined elements of similar shape in chicken as "caliciform cells". The lack of microvilli, RER, free ribosomes, Golgi apparatus scarcely represented and the presence of abundant mitochondria rather suggest that they play a role in water and electrolyte transport, which is in agreement with the hypothesis of Vinnicombe and Kendall (1983) for similar cells revealed in the starling.

On account of their structural features and the presence of numerous pleomorphic and swollen mitochondriae, they could also be related to a cell type defined by Egerb acher and Böck (1997) as "oncocyte" in the human pancreatic duct epithelium. Our findings, obtained by structural and ultrastructural observations, therefore suggest that the main and globose cells, lining the pancreatic duct epithelium in the ostrich pancreas, have the functional capacity to define the composition of pancreatic juice.

In conclusion, our findings contribute to the knowledge of the organization of the ostrich pancreas and its pancreatic duct by providing both macroscopical and histological details. In particular, the pancreatic duct presents structural peculiarities, with respect to other avian species, clearly related to the particular nature of the ostrich digestive process. 


\section{Morfologická studie pankreatu a sekretorického systému u pštrosů}

Zvláštnosti procesů trávení u pštrosů a nedostatek literárních údajů o pankreatu a jeho exkretorickém systému u tohoto druhu vedly $\mathrm{k}$ zájmu autorů studovat na makroskopické i histologické úrovni možné rozdíly oproti jiným druhům ptáků. Naše nálezy ukázaly na přítomnost dvou laloků pankreatu, dorsálního a ventrálního, a třetího, splenického, který lze identifikovat pouze histologicky. Nejzajímavější data byla získána o počtu, průběhu a strukturálních zvláštnostech pankreatického vývodu. Strukturální a ultrastrukturální charakteristika dvou buněčných typů, vystýlajících ductus pancreaticus (hlavní a globózní buňky) naznačuje jejich roli v sekreci a resorpci pankreatické štávy. Výsledky práce umožňují pochopit zvláštnosti trávení u tohoto aviárního druhu.

\section{References}

BEZUIDENHOUT AJ 1986: The topography of the thoraco-abdominal viscera in the ostrich (Struthio camelus L.). Onderstepoort J Vet Res 53 (2): 111-117

BOTTE V, PELAGALLI GV 1982: Anatomia funzionale degli uccelli domestici. Edi Ermes, Milano.

EGERBACHER M, BÖCK P 1997: Morphology of the pancreatic duct system in mammals. Microsc Res Tech 37: 407-417

LIU JW, EVANS H, LARSEN P, PAN D, XU SZ, DONG HC, DENG XB, WAN B, GI T 1998: Gross anatomy of the pancreatic lobes and ducts in six breeds of domestic duck and six species of wild ducks in China. Anat Histol Embryol 27: 413-417

NICKEL R, SCHUMMER A, SEIFERLE E 1984: Trattato di Anatomia degli animali domestici vol. V. Casa editrice Ambrosiana, Milano

PAIK YK, FUJIOKA T, YASUDA M 1974: Comparative and topographical anatomy of the fowl. LXXVIII. Division of pancreatic lobes and distribution of pancreatic ducts. Jpn J Vet Sci 36: 213-229

SISSON S, GROSSMAN JD 1982: Anatomia degli animali domestici vol. 2. Piccin Editore, Padova

TURK DE 1983: The anatomy of the avian digestive tract as related to feed utilization. Poult Sci 61: 1225-1244

VINNICOMBE SJ, KENDALL MD 1983: The accessory pancreatic ducts of the starling Sturnus vulgaris: an ultrastructural and light microscopic study. J Anat 137: 341-355

WEYRAUCH KD, SCHNORR B 1978: The fine structure of the epithelium of the main outlets from the liver and pancreas of the domestic chicken. Anat Anz 143: 37-49 
Plate I

Stornelli M. R. et al.: Morpho-structural Study ... pp. 157-160

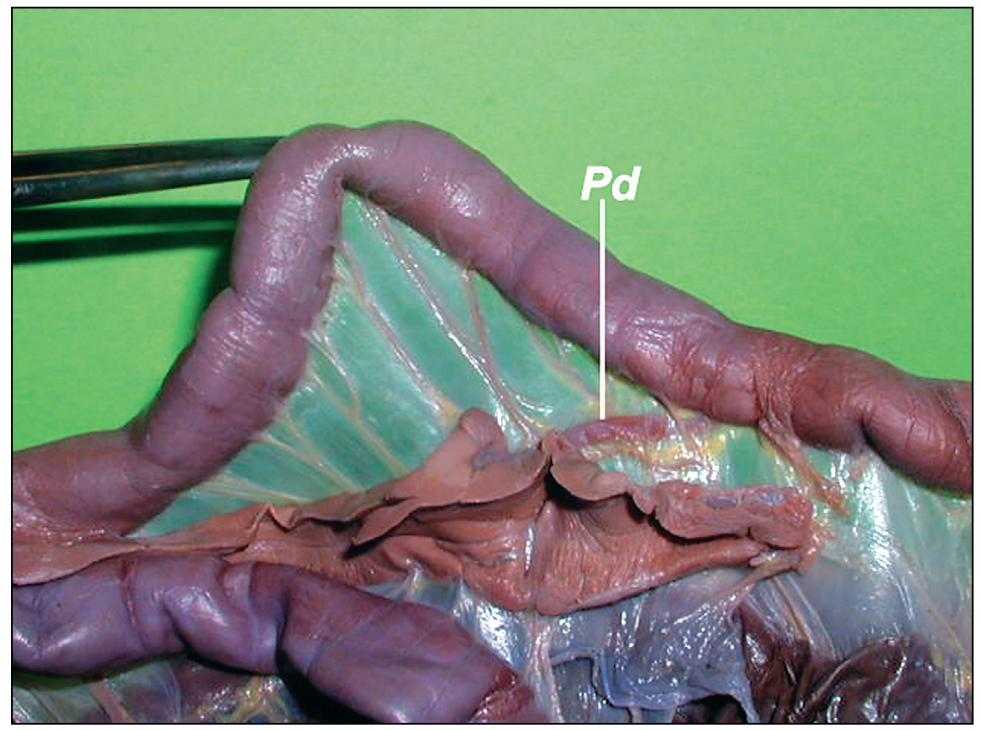

Fig. 1. Pancreas in the duodenal loop with the pancreatic duct (Pd).

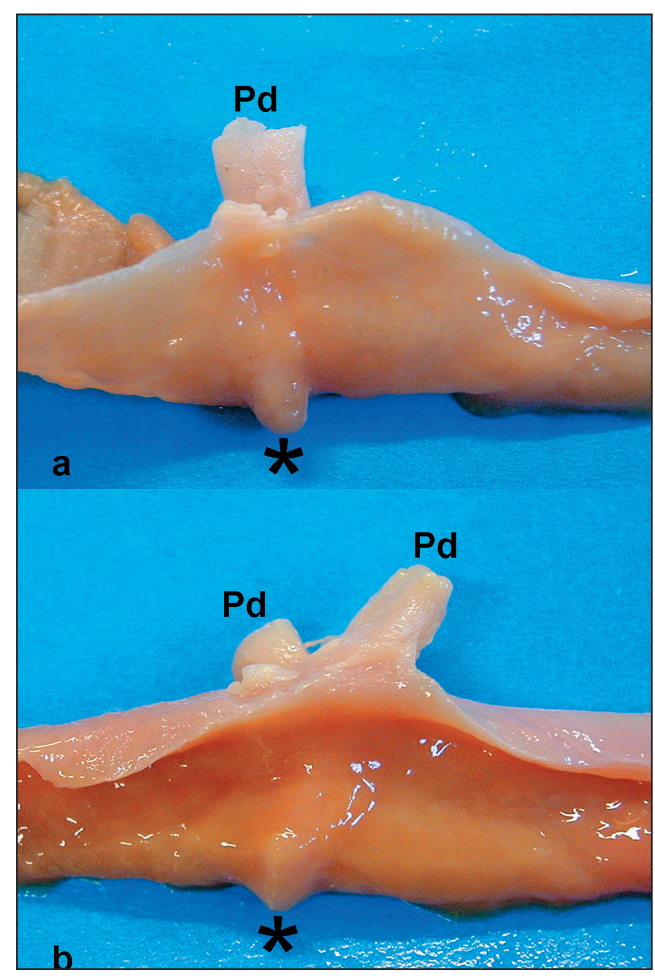

Fig. 2. (a) Pancreatic duct opening in the duodenal papilla (*) and an unusual presence of two pancreatic ducts (b). 
Plate II

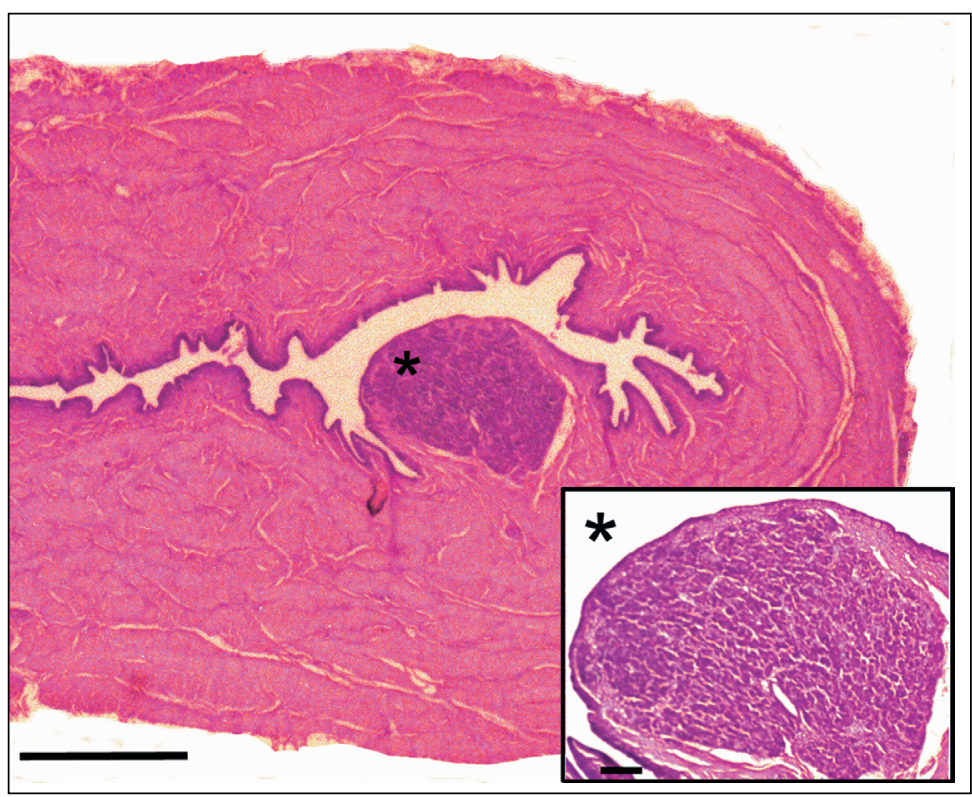

Fig. 3. Pancreatic duct with accessory pancreas (*) in the lamina propria. PAS / H. Scale bar 250 $\mu \mathrm{m}$. Square scale bar $100 \mu \mathrm{m}$.

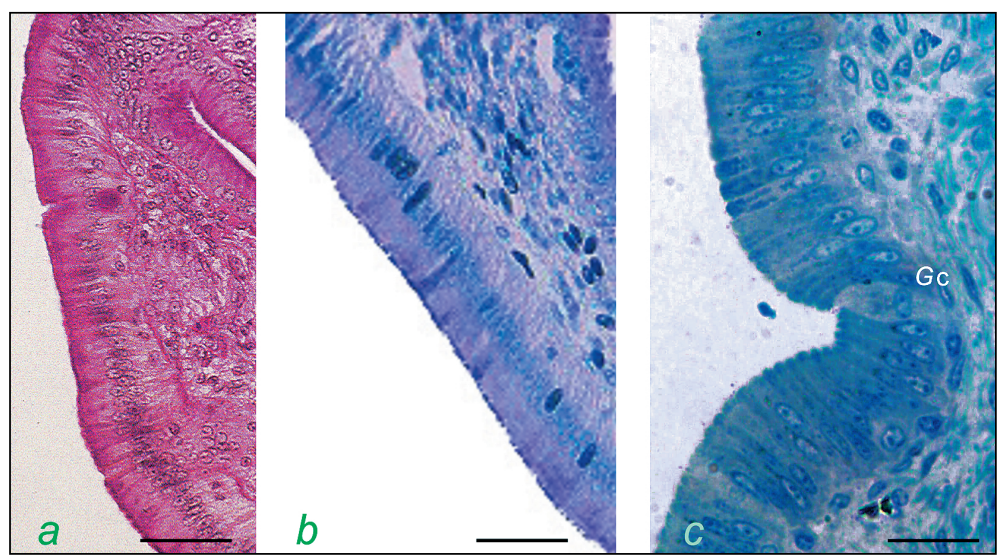

Fig. 4. Simple columnar epithelium of the pancreatic duct with PAS positive (a) and metachromatic granules (b). Globose cell (Gc) between the main cells which show variable tinctorial affinity (c). PAS/H, toluidine blue, toluidine blue + methylene blue. Scale bar $30 \mu \mathrm{m}$. 


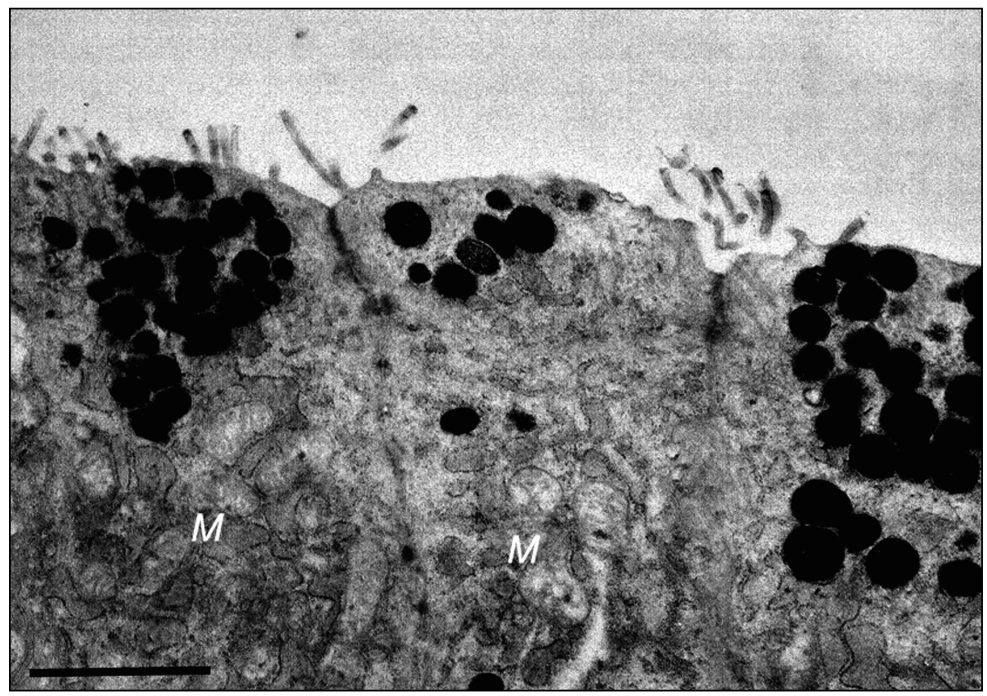

Fig. 5. Main cells with microvilli, electron-dense granules and mitochondria (M) with tubular cristae. Adhesion structures are visible between adjacent cells. Scale bar $2 \mu \mathrm{m}$.

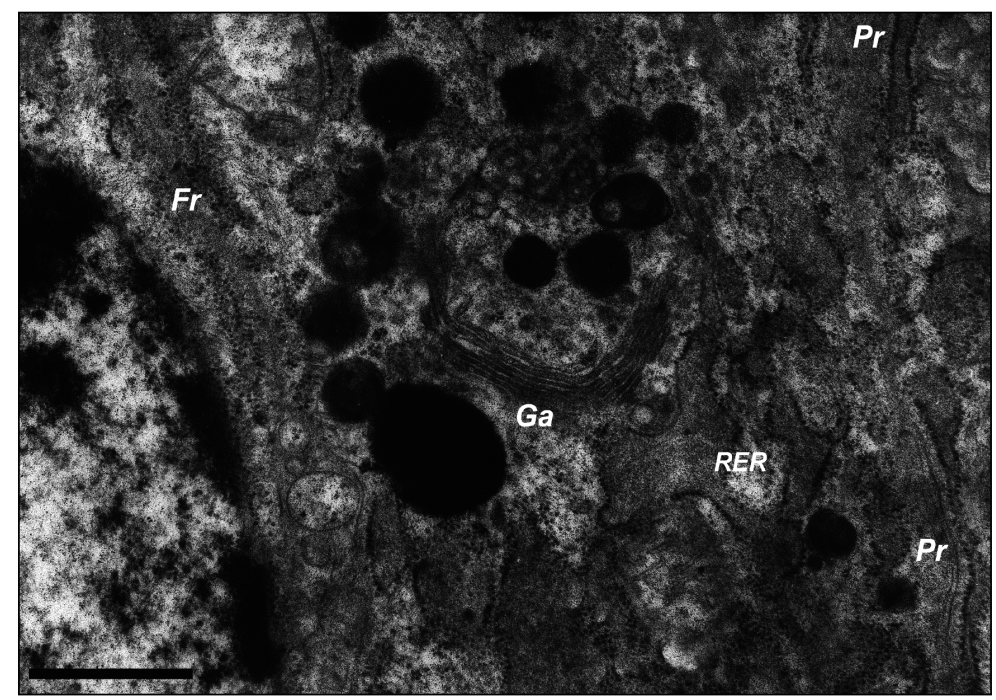

Fig. 6. Main cell: Golgi apparatus (Ga), RER and ribosomes free (Fr) or organized in to polyribosomes (Pr). Scale bar $1 \mu \mathrm{m}$. 


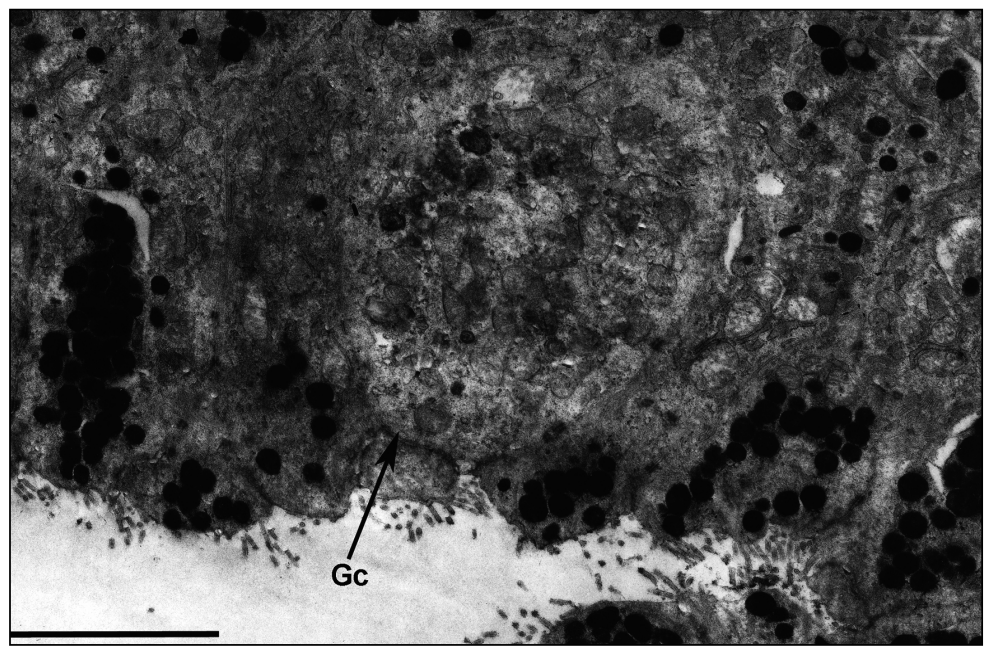

Fig. 7. Globose cell (Gc) with numerous swollen mitochondria and clear vescicles. Scale bar $5 \mu \mathrm{m}$. 